\title{
ОЦІНКА РИЗИКУ ВИНИКНЕННЯ КАРДІОВАСКУЛЯРНИХ УСКЛАДНЕНЬ У ПАЦІЄНТІВ ІЗ ПОДАГРОЮ
}

\author{
С. В. Даньчак, О. В. Прокопчук, Л. В. Першина \\ Комунальне некомерційне підприємство Харківської обласної ради \\ "Обласна клінічна лікарня"
}

У статті наведено результати оцінки ризику виникнення кардіоваскулярних ускладнень у пацієнтів із подагрою.

\section{ASSESSMENT OF CARDIOVASCULAR RISK FACTORS IN PATIENTS WITH GOUT}

\author{
S. V. Danchak, O. V. Prokopchuk, L. V. Pershyna
}

\section{Communal nonprofit enterprise of Kharkiv Regional Council "Regional Clinical Hospital"}

The article represents the assessment data of cardiovascular risk factors in patients with gout.

Вступ. Загальновідомим є факт, що хворі на подагру мають підвищений ризик виникнення серцевосудинних захворювань. 3 метою вивчення частоти кардіоваскулярного ризику обстежено 68 хворих на первинну подагру. Для визначення кардіоваскулярного ризику використовували таблицю SCORE. Встановлено, що у пацієнтів з подагрою спостерігали підвищення кардіоваскулярного ризику. До факторів ризику розвитку кардіоваскулярних захворювань у хворих на подагру належать артеріальна гіпертензія, гіперхолестеринемія, гіперурикемія, зростання віку хворих, збільшення індексу маси тіла, куріння. Встановлено, що рівень гіперурикемії зростав із збільшенням ризику виникнення кардіоваскулярних катастроф.

Основна частина. У хворих на подагру, порівняно з іншими ревматологічними захворюваннями, значно частіше спостерігають серцево-судинні захворювання [1], а у хворих із доведеним атеросклерозом, в свою чергу, виявляють підвищену концентрацію сечової кислоти [2], внаслідок чого вважають, що гіперурикемія $\epsilon$ незалежним предиктором кардіоваскулярної захворюваності та смертності у хворих на ішемічну хворобу серця, хронічну та гостру серцеву недостатність, артеріальну гіпертензію і метаболічний синдром $[3,6]$. У зв'язку з тим, що гіперурикемію, в

(ㄱ С. В. Даньчак, О. В. Прокопчук, Л. В. Першина, 2019 світлі останніх наукових досліджень, розглядають як незалежний чинник ризику розвитку та прогресування серцево-судинних захворювань [7-10], а робіт у галузі медсестринства, присвячених цьому питанню, недостатньо, питання оцінки кардіоваскулярного ризику в цієї категорії пацієнтів є досить актуальним.

Мета дослідження - вивчити частоту кардіоваскулярного ризику та фактори ризику розвитку кардіоваскулярних захворювань у пацієнтів із подагрою.

Для реалізації мети обстежено 68 хворих на первинну подагру. Всю групу обстежених склали чоловіки віком 24-78 років, серед яких молодого віку - 12,6 \%, середнього віку - 39,0 \%, літнього віку - 11,0 \%, старечого віку - 3,3 \% осіб. Потрібно зауважити, що більшість обстежених належали до осіб працездатного віку (хворі молодого та середнього віку), що, в свою чергу, підкреслює актуальність вивчення цієї проблеми.

Діагноз подагри верифікували згідно із наказом МО3 України від 12.10.2006 р. № 676. Критеріями виключення були наявність в анамнезі чи на момент огляду хронічних вірусних гепатитів В і С, автоімунного та медикаментозного гепатиту і алкогольного ураження печінки (верифікований діагноз «алкогольне захворювання печінки», або встановлено щоденне вживання алкоголю у високих дозах ( $\geq 40$ г етанолу для чоловіків)). Також для виключення алкогольної 
хвороби печінки застосовували опитувальник CAGE та тест для ідентифікації порушень, зумовлених вживанням алкоголю (AUDIT).

Керуючись європейськими рекомендаціями з профілактики серцево-судинних захворювань (2003р.), для визначення кардіоваскулярного ризику (КВР) використовували таблицю SCORE (Systematic Coronary Risk Evolution).

Статистичну обробку даних виконували за допомогою стандартного пакета програм SPSS версії 17.0 та Microsoft Excel. Кількісні зміни подано у вигляді середньої величини та стандартної похибки середньої величини (M+SE), якісні - у відсотках. Розбіжність між показниками вважали достовірною, якщо значення вірогідності дорівнювало або перевищувало $95 \%$ $(p<0,05)$.

Оцінка поширеності факторів ризику виникнення КВР (табл. 1) у пацієнтів констатувала, що артеріальну гіпертензію, гіперхолестеринемію спостерігають в більшості випадків та корелюють з підвищенням рівня систолічного та діастолічного артеріального тиску.

Таблиця 1. Поширеність факторів ризику виникнення кардіоваскулярних ризиків

\begin{tabular}{|l|c|}
\hline \multicolumn{1}{|c|}{ Показник } & $\begin{array}{c}\text { Хворі, } \\
\mathrm{n}=68\end{array}$ \\
\hline Артеріальна гіпертензія, $\mathrm{n}$ & $51(75)$ \\
Систолічний АТ, мм рт. ст. & $151,40 \pm 17,95$ \\
Діастолічний АТ, мм рт. ст. & $88,46 \pm 16,21$ \\
\hline Гіперхолестеринемія, $\mathrm{n}$ & $49(72,1)$ \\
3ХС, ммоль/л & $6,23 \pm 1,12$ \\
\hline Вік (роки) & $56,96 \pm 9,16$ \\
\hline ІМТ & $32,09 \pm 4,52$ \\
\hline Не курять, $\mathrm{n}(\%)$ & $25(36,8)$ \\
Ексюзер, $\mathrm{n}(\%)$ & $10(14,7)$ \\
Курять, $\mathrm{n}(\%)$ & $33(48,5)$ \\
\hline Гіперурикемія, $\mathrm{n}(\%)$ & $65(95,6)$ \\
Сечова кислота, ммоль/л & $0,72 \pm 0,11$ \\
\hline
\end{tabular}

Визначення відсотка осіб щодо статусу куріння виявило той факт, що більша кількість хворих курить на даний момент, менша кількість курила в минулому. Варто зауважити, що 36,8 \% осіб не курять і не курили в минулому. Значний відсоток хворих із гіперурикемією (95,6 \%) корелював з концентрацією сечової кислоти в плазмі крові.

Вивчаючи динаміку показника КВРу досліджуваних пацієнтів було встановлено, що низький ризик спостерігають у 16,2 \%, помірний -у 25,0\%, високий - в 19,1\% і дуже високий ризик - у 39,7 \% випадків (табл. 2). Також виявлено, що у молодих осіб наявні в однаковій кількості лише низький та помірний ризики. Щодо осіб середнього віку, то в цьому випадку КВР виявлено від низького до дуже високого, з найбільшим відсотковим залученням пацієнтів до груп помірного та високого КВР. Збільшення ризику кардіоваскулярних катастро ф характерне для пацієнтів старечого віку.

У процесі дослідження встановлено, що рівень загального холестеролу в межах норми притаманний лише особам із низьким та помірним КВР. Максимальний рівень загального холестеролу, що достовірно перевищував допустимі норми, зафіксовано серед осіб із дуже високим КВР.

\section{Таблиця 2. Розподіл хворих за показниками кардіоваскулярних ризиків}

\begin{tabular}{|l|c|}
\hline \multicolumn{1}{|c|}{ Показники, $\mathrm{n}(\%)$} & $\begin{array}{c}\text { Хворі, } \\
\mathrm{n}=68\end{array}$ \\
\hline Низький & $11(16,2)$ \\
\hline Помірний & $17(25,0)$ \\
\hline Високий & $13(19,1)$ \\
\hline Дуже високий & $27(39,7)$ \\
\hline
\end{tabular}

Аналіз рівня сечової кислоти (рис. 1) демонстрував зростання концентрації в плазмі крові останньої зі збільшенням рівня кардіоваскулярного ризику.

Варто відзначити, що у деяких пацієнтів не вдалося досягти задовільних результатів лікування, що, в свою чергу, свідчить про неадекватні дози гіпоурикемічних препаратів.

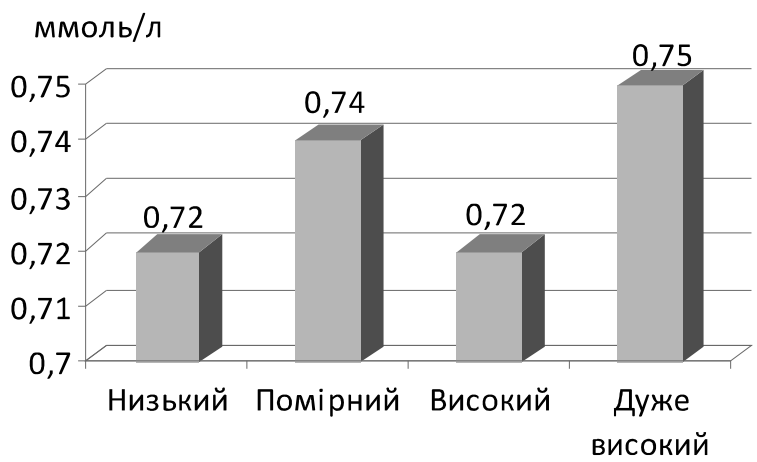

Рис. 1. Рівень сечової кислоти при різному ступені КВР.

Висновки. 1. У пацієнтів із подагрою спостерігають підвищення кардіоваскулярного ризику, причому низький ризик виявляють у 16,2 \%, помірний в 25,0\%, високий - у 19,1 \% і дуже високий ризик у $39,7 \%$ випадків.

2. До факторів ризику розвитку кардіоваскулярних захворювань у хворих на подагру належать артеріальна гіпертензія, гіперхолестеринемія, гіперурикемія, зростання віку хворих, збільшення індексу маси тіла, куріння. 
3. Встановлено, що рівень гіперурикемії був достовірно $(p<0,01)$ вищим та зростав зі збільшенням ризику виникнення кардіоваскулярних катастроф, при

\section{СПИСОК ЛІТЕРАТУРИ}

1. Increased cardiovascular risk factors in different rheumatic diseases compared with the general population / I. L. Meek, H. S. Picavet, H. E. Vonkeman, W. M. Verschuren // Rheumatology (Oxford). - 2013. - No. 52. - P. 210-216.

2. Roddy E. Epidemiology of gout / E. Roddy, M. Doherty // Arth. Res. Ther. - 2010. - No. 12 (223). - P. 1-11.

3. Bhatia L. S. Non-alcoholic fatty liver disease: a new and important cardiovascular risk factor? / L. S. Bhatia // Eur. Heart J. - 2012. - Vol. 33. - P. 1190-1200.

4. Особливості вуглеводного та ліпідного обміну у хворих на неалкогольну жирову хворобу печінки залежно від ступеня кардіоваскулярного ризику / О. В. Колеснікова, О. Я. Бабак, Т. А. Соломенцева [та ін.] // Сучасна гастроентерологія. - 2013. - № 6. - С. 7-12.

5. Chalasani N. The diagnosis and management of nonalcoholic fatty liver disease: Practice guideline by the American Gastroenterological Association, American Association for the Study of Liver Diseases, and цьому досягти максимальних значень в осіб із встановленим дуже високим кардіоваскулярним ризиком.

American College of Gastroenterology / N. Chalasani // Gastroenterology. - 2012. - Vol. 142. - P. 1592-1609.

6. Sung K. C. Fatty liver, insulin resistance, and features of metabolic syndrome: relationships with coronary artery calcium in 10,153 people / K. C. Sung // Diabetes Care.2012. - Vol. 35. - P. 2359-2364.

7. Relationship between nonalcoholic fatty liver disease and metabolic syndrome / S. H. Chen, F. He, H. L. Zhou [et al.] // J. Dig. Dis. - 2011. - Vol. 12. - P. 125-130.

8. ALDR enhanced endothelial injury in hyperuricemia screened using SILAC / Y. Zhang, Q. Hong, Z. Huang [et al.] // Cell. Physiol. Biochem. - 2014. - Vol. 33 (2). - P. 479-490.

9. Independent association between nonalcoholic fatty liver disease and cardiovascular disease in the US population / M. Stepanova, Z. M. Younossi // Clin. Gastroenterol. Hepatol. - 2012. - Vol. 10 (6). - P. 646-650.

10. Targher G. Risk of all-cause and cardiovascular mortality in patients with chronic liver disease / G. Targher // Gut. - 2011. - Vol. 60. - P. 1602-1603. 